\title{
LA AUTONOMÍA DE LA VOLUNTAD Y PROTECCIÓN DEL CÓNYUGE MÁS DÉBIL EN LA DETERMINACIÓN Y FORMAS DE PAGO DE LA COMPENSACIÓN ECONÓMICA*
}

\author{
AUTONOMY OF WILL AND PROTECTION OF THE WEAKER SPOUSE \\ IN THE DETERMINATION AND FORM OF PAYMENT OF \\ ECONOMIC COMPENSATION
}

CRISTIÁn LePín Molina*

\begin{abstract}
RESUMEN
El presente trabajo tiene por objeto analizar cómo operan los principios de protección del cónyuge más débil y de autonomía de la voluntad, en dos aspectos específicos del derecho a compensación económica consagrado en los artículos 61 a 66 de la Nueva Ley de Matrimonio Civil, como son la determinación del derecho, ya sea por acuerdo entre los cónyuges o por determinación judicial, y también en un aspecto que ha cobrado relevancia en los últimos años como son las distintas formas de pago de la prestación compensatoria.

ABSTRACT

This paper examines how the principles of protection of weaker spouse and autonomy of will operate in two specific aspects of the right to compensation as set out in Articles 61 to 66 of the New Civil Marriage Act, such as the determination of right, either by agreement between the spouses or by court order, and also the different ways of payment of the compensatory allowance, an area that has gained importance in recent years.

PalabRas Clave Compensación Económica, Autonomía de la Voluntad, Cónyuge Débil,

Formas de Pago

KEYWORDS

Compensation, Autonomy of Will, Weaker Spouse, Forms of Payment
\end{abstract}

\footnotetext{
* Trabajo recibido el 8 de marzo y aprobado el 20 de abril de 2012.

** Licenciado en Ciencias Jurídicas y Sociales, Abogado, Magíster en Derecho por la Universidad de Chile, Doctorando en Derecho Civil por la Universidad de Buenos Aires, profesor de la Facultad de Derecho de la Universidad de Chile, de pre y postgrado, Coordinador Académico de la Escuela de Postgrado, de la misma Universidad, Profesor de Derecho Civil de la Facultad de Derecho de la Universidad Central de Chile. Correo electrónico clepin@derecho.uchile.cl. El autor agradece a los investigadores de la Escuela de Postgrado de la Facultad de Derecho de la Universidad de Chile, Karen Muñoz y Sergio Cortés por su valiosa colaboración en la preparación de este artículo.
} 


\section{INTRODUCCIÓN}

La compensación económica es el derecho que le asiste a uno de los cónyuges al momento de la ruptura matrimonial, sea que ésta se haya producido por divorcio o por nulidad del matrimonio, para que se le compense el menoscabo económico sufrido por no haber podido desarrollar total o parcialmente una actividad remunerada, como consecuencia de haberse dedicado al cuidado de los hijos o del hogar común'.

Este derecho, incorporado por nuestro legislador en la Ley $N^{\circ} 19.947$, Nueva Ley de Matrimonio $\mathrm{Civil}^{2}$, ha generado una serie de interrogantes. Mucho se ha discutido sobre sus aspectos dogmáticos, como sus fundamentos y naturaleza jurídica, lo que ha despertado el interés de académicos, estudiantes y operadores del derecho en general. Sin embargo, parece también interesante desarrollar otros tópicos, como, por ejemplo, los principios, los criterios para determinar su monto, las formas de pago, las seguridades para el pago, los apremios y otras maneras de obtener su cumplimiento.

En este trabajo, en primer lugar, analizaremos cómo operan en la compensación los principios de autonomía privada y protección del cónyuge débil; luego, cómo influyen estos principios en la determinación de la prestación compensatoria tanto por las partes (artículo 63 NLMC) como por el juez (artículo 64 NLMC), además de sus diversas formas de pago.

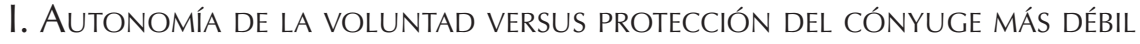

Importa en este apartado esclarecer el rol del principio de protección del cónyuge más débil y el principio de autonomía privada en la determinación de la compensación económica y en sus formas de pago. Para estos efectos, en primer lugar, se realizará una referencia a la incorporación del principio de protección al cónyuge más débil y una aproximación a su contenido y alcance; para luego revisar someramente el avance de la autonomía de la voluntad en materia de familia.

\section{La protección del cónyuge más débil}

La ley № 19.947 entró en vigencia el 18 de noviembre de 2004, e incorporó, por primera vez en la legislación chilena el divorcio vincular. Con ello surgió, desde la presentación del proyecto de ley en el año 1995 y durante toda su tramitación, la preocupación por proteger al cónyuge que al momento de la

\footnotetext{
${ }^{1}$ Lepín Molina, Cristián, La compensación económica. Efecto patrimonial de la terminación del matrimonio, Editorial Jurídica de Chile, Santiago, 2010, p. 58.

2 En adelante NLMC.
} 
ruptura queda en una precaria situación económica ${ }^{3}$. En un primer momento, esta preocupación se expresa a través de la idea de la exigencia de establecer relaciones equitativas entre los cónyuges hacia el futuro y procurar aminorar el daño que pudo causar la ruptura, en los casos de divorcio y especialmente al presentar un convenio regulador de las relaciones familiares ${ }^{4}$.

Posteriormente, en el segundo trámite constitucional, se fortalece la idea de proteger al cónyuge más débil, mediante la incorporación del derecho de compensación económica, además de la denominada "cláusula de dureza" que permite al juez rechazar el divorcio en caso de incumplimiento por parte del cónyuge demandante de la obligación alimenticia respecto del otro cónyuge o los hijos.

Por último, otra medida tendiente a asegurar esa protección sería el control que podría realizar el juez al aprobar un convenio regulador, calificándolo de completo y suficiente.

A su vez, el legislador chileno incorpora en el artículo $3^{\circ} \mathrm{NLMC}$ el deber del juez de familia de resolver los conflictos familiares, cuidando proteger siempre el interés superior de los hijos y del cónyuge más débil.

El principio de protección del cónyuge más débil, como se ha señalado, fue reconocido e incorporado expresamente por la NLMC. Por tanto, sólo sería aplicable a las materias reguladas por ésta.

No obstante, esta afirmación resulta discutible, ya que algunos autores han señalado que "no se trata de un principio creado por la Ley de Matrimonio Civil, pues ya estaba consagrado en el Código Civil, por ejemplo, en las normas relativas a los bienes familiares (artículos 141 a 149); en las disposiciones de la sociedad conyugal destinadas a proteger a la mujer (especialmente en lo que se refiere a las limitaciones a la administración ordinaria de la sociedad conyugal, establecidas en el artículo 1749; en las normas que favorecen a la mujer para el

\footnotetext{
${ }^{3}$ Instituto Libertad y Desarrollo, "Divorcio unilateral empeora la situación de la mujer". En: http://www. lyd.com/programas/legislativo/divorcio [visitado el 10/06/2011]. Véase Boletín del Senado № 1.75918, Informe de la Comisión de Constitución, Legislación, Justicia y Reglamento del Senado, "Aspectos económicos del divorcio", pp. 1170 y ss.

${ }^{4}$ En el texto propuesto podemos encontrar dos disposiciones que hacen referencia al tema en comento: el art. 63, que pretendía establecer el convenio regulador de las relaciones familiares, como una regla común a la separación, nulidad y divorcio, que en su parte final señalaba "es suficiente cuando, al referirse a cada una de las materias que se acaban de señalar, resguarda suficientemente el interés de los hijos, procura aminorar el daño que pudo causar la ruptura y establece relaciones equitativas hacia el futuro entre quienes ahora se divorcian...", y el art. 65, que en su inciso final establecía que "al respecto, y por resolución fundada, el juez podrá alterar las reglas de la distribución de gananciales o del crédito de participación, si los hubiere; disponer pensiones alimenticias por tiempo limitado a favor de los cónyuges; o prever otra prestación que asegure a favor de los hijos o el cónyuge relaciones equitativas". La moción parlamentaria que da origen a la ley $N^{\circ} 19.947$, presentada el 28 de noviembre de 1995, por la diputada señorita Saa, señoras Allende y Aylwin, y los diputados señores Walker, Barrueto, Cantero, Longton, Munizaga, Elgueta y Viera-Gallo.
} 
pago de las recompensas que se le adeuden al liquidarse la sociedad conyugal, según lo dispuesto en el artículo 1773; y en el beneficio de emolumento que opera a favor de la mujer, consagrado en el artículo 1777); y en aquellas que se consagran en el crédito de participación en los gananciales al término de dicho régimen (artículos 1792-20 al 1792-26). Lo mismo ocurre con las normas de alimentos, tanto del Código Civil (artículos 321 al 337) como de la Ley 14.908 sobre Abandono de Familia y Pago de Pensiones Alimenticias" ${ }^{\prime 5}$.

Resulta interesante la reflexión en torno a la incorporación del principio en comento, toda vez que al tomar partido por una de las alternativas ya señaladas, se estará determinando el ámbito de aplicación de este principio. Recordemos que la NLMC regula lo concerniente a la celebración del matrimonio y el término del mismo, mientras que todo lo relativo a las relaciones de los cónyuges durante el matrimonio se regula, en nuestra legislación, en el Código Civil ${ }^{6}$.

En consecuencia, si estimamos que sólo fue reconocido e incorporado por el artículo $3^{\circ} \mathrm{NLMC}$, su aplicabilidad se restringiría a la celebración y a la ruptura del matrimonio, debiendo descartarse su intervención durante la época que dure el matrimonio. Ésta parece ser la intención del legislador, ya que del tenor literal del citado artículo $3^{\circ}$, se puede concluir que es un mandato dirigido al juez llamado a resolver el conflicto, principalmente en situaciones de quiebre matrimonial. El inciso $1^{\circ}$ del artículo $3^{\circ}$ señala que "las materias de familia reguladas por esta ley deberán ser resueltas cuidando proteger siempre el interés superior de los hijos y del cónyuge más débil'"n.

En las actas de la NLMC, existe registro de que la preocupación de los legisladores al regular el divorcio vincular era la situación en que quedaban la mujer y los hijos al momento del término del matrimonio. Especial interés expresaron por la desigualdad en las condiciones económicas y el poder de negociación de éstos al momento de la ruptura. Así, la diputada señorita Saa señaló durante el debate que "en el caso de la nulidad, el matrimonio termina, pero las mujeres y los hijos no tienen fuerza para negociar las condiciones en que quedan. En la práctica la nulidad somete al cónyuge más débil al poder económico del otro. Esto significa que mediante el dinero, el cónyuge más fuerte podrá lograr una nulidad favorable amenazando, por ejemplo, con dejar de pagar la alimentación, la vivienda, la

\footnotetext{
${ }^{5}$ Orrego Acuña, Juan, Análisis de la Nueva Ley de Matrimonio Civil, Metropolitana, Santiago, 2004, nota al pie de página, pp. 20 y 21.

${ }^{6}$ Así, el Código Civil regula lo concerniente al matrimonio en el Título IV "Del Matrimonio" arts. 102 a 123; en el Título V "De las Segundas Nupcias" arts. 124 a 130; en el Título VI "Obligaciones y Derechos entre los cónyuges" arts. 131 a 178; en el Título XXII "De las convenciones matrimoniales y de la sociedad conyugal" arts. 1715 a 1792, y en el Título XXII-A "Régimen de la participación en los gananciales" arts. 1792-1 a 1792-27.
}

${ }^{7}$ Boletín del Senado N 1.759-18, cit. n. 3, pp. 447 y 448. 
salud y los colegios. El resultado es que el cónyuge más débil se ve obligado a aceptar las condiciones de quien tiene el dinero. Agrega que la realidad indica que la mayoría de los cónyuges más débiles son mujeres, porque el 65 por ciento de ellas no tiene trabajo remunerado y muchas han dedicado su vida a atender el hogar, a los hijos y al marido. Por lo tanto, no tienen asegurada por sí mismas la atención en caso de enfermedad, de invalidez o vejez, o su propia mantención, mientras que los maridos, en su mayoría, perciben una remuneración por su trabajo y financian su previsión con el dinero de la sociedad conyugal"8.

También se expresó que "la Comisión acordó tratar separadamente el tema planteado en el artículo $38^{9}$ de la indicación de S.E. el Presidente de la República

${ }^{8}$ Boletín del Senado № $1.759-18$, cit. n. 3, p. 118. Similares argumentos en las pp. 285, 419 y 433.
${ }^{9}$ Indicación Proyecto de Ley, artículo 38: "Deberá evitarse que, como consecuencia del divorcio,
alguno de los cónyuges quedare imposibilitado de su mantención, considerando las resultas de la
liquidación del régimen de bienes que existiere, o el estado de separación de bienes, la existencia de bienes familiares y la eventual provisión de alimentos que hubiere existido entre ellos.

Si el divorcio generare una situación de esa naturaleza, el tribunal podrá adoptar una o más de las siguientes medidas a favor del cónyuge afectado:

Proceder a la declaración de bienes familiares.

Constituir derechos de usufructo, uso o goce respecto de bienes que hubieren conformado parte del patrimonio familiar de los cónyuges.

Determinar el pago de un monto o de una pensión compensatoria por un período de tiempo que no exceda de los cinco años, contados desde la fecha en que quede ejecutoriada la sentencia que decreta el divorcio.

Las medidas se adoptarán a petición de parte, pudiendo solicitarse en forma conjunta a la demanda de divorcio o por vía reconvencional en el mismo procedimiento. En ambos casos, deberá resolverse en la sentencia definitiva.

Para acceder a la solicitud y precisar la medida, el tribunal deberá considerar especialmente lo siguiente:

$1^{\circ}$ La duración del matrimonio y de la vida en común de los cónyuges;

$2^{\circ}$ La edad, estado de salud y capacidad económica de ambos cónyuges;

$3^{\circ}$ Las facultades de sustento individual de los cónyuges, considerando especialmente las posibilidades de acceso al mercado laboral;

$4^{\circ}$ La eventual colaboración común que hayan realizado los cónyuges a la actividad que haya servido de sustento al núcleo familiar;

$5^{\circ} \mathrm{El}$ aporte y dedicación brindado por los cónyuges a las labores no remuneradas que demanda el cuidado de los hijos y del hogar común;

$6^{\circ}$ La eventual pérdida de beneficios previsionales que deriven del divorcio;

$7^{\circ}$ La existencia previa al divorcio de una pensión de alimentos entre los cónyuges.

Las medidas impuestas en virtud de lo dispuesto en el presente artículo no procederán respecto del cónyuge que haya dado lugar al divorcio por falta que le sea imputable.

En todo caso podrá solicitarse su modificación o cese, si hubieren variado las circunstancias que motivaron el establecimiento.

En los casos previstos en las letras a) y b) del presente artículo, el cónyuge divorciado que no fuere beneficiario de la medida, podrá solicitar al tribunal el cese de la misma una vez transcurridos 5 años desde su imposición, para el solo efecto de proveer su enajenación. En este caso, la resolución que conceda la solicitud deberá determinar el porcentaje de la enajenación que corresponda al cónyuge beneficiario, a título compensatorio". 
y en el artículo $48^{10}$ inciso segundo, de la indicación de los Honorables Senadores señores Chadwick y Romero y del ex Senador señor Díez, acerca de la protección legal que recibiría el cónyuge más débil, en caso de término del matrimonio"11.

La protección al cónyuge más débil, consagrado en el citado artículo $3^{\circ}$, presenta una serie de interrogantes, tanto en cuanto su contenido como con respecto a su alcance.

Según Carmen Domínguez, refiriéndose a la compensación económica, "la única forma de entender esta figura es como 'la' forma concreta de tutela del cónyuge más débil que la ley contiene. En efecto, es indudable que esta normativa, al introducir el divorcio vincular unilateral, privó al cónyuge más débil que se opone a él de todo poder de negociación. En efecto, éste (más bien ésta en la mayoría de los casos) ya no dispone de medios para oponerse al divorcio unilateral, de suerte que no tiene modo de evitar la pérdida de todos los derechos que provenían de su relación conyugal"12.

Pero cabe preguntarse qué debemos entender por cónyuge débil.

No lo define la ley, sin embargo, la doctrina ha señalado que podemos entender como tal "al que se encuentre en una posición económica, psíquica, emocional o fisiológica desmedrada"13. En otros términos, la ley nos remite a la realidad concreta de cada caso ${ }^{14}$. Para Guerrero, en cambio, es fácil constatar que la NLMC no define qué debe entenderse por cónyuge más débil, sin embargo, de la discusión parlamentaria no cabe duda de que se legisló pensando en proteger a aquel cónyuge que se encontrará, con ocasión de la ruptura matrimonial, en un posición de desmedro económico frente al otro, para comenzar su vida de forma separada e independiente ${ }^{15}$.

\footnotetext{
${ }^{10}$ Indicación Proyecto de Ley, artículo 48: "Por la declaración de nulidad se tendrá el matrimonio como no celebrado para todos los efectos legales.

No obstante, el presunto cónyuge que hubiere contraído de buena fe y que haya tenido a su cargo el cuidado del hogar o de los hijos comunes, tendrá derecho a solicitar que el otro cónyuge le proporcione alimentos durante un plazo que no excederá de cinco años contados desde que quede ejecutoriada la sentencia que declara la nulidad".

${ }^{11}$ Boletín del Senado No 1.759-18, cit. n. 3, p. 587.

${ }^{12}$ Domínguez Hidalgo, Carmen, "Compensación económica en la nueva ley de matrimonio civil", Seminario del Colegio de Abogados, charla efectuada 13 de octubre, Santiago, 2005, p. 9.

${ }^{13}$ Rodríguez Grez, Pablo, Ley de matrimonio civil, en: <www.abogados.cl> [visitado el 10/06/2010].

${ }^{14}$ Gómez de la Torre Vargas, Maricruz, "Compensación económica en la nueva ley de matrimonio civil", Seminario Colegio de Abogados, charla efectuada el 20 de octubre, Santiago, 2005, p. 5.

${ }^{15}$ Guerrero Becar, José. "Menoscabo y compensación económica. Justificación de una visión asistencial", Revista Derecho (Valdivia), Vol. 21, № 2, 2008, p. 102. Y Hübner Guzmán, Ana. "La nueva Ley de matrimonio civil: panorama y estructura general", en Assimakópulos Figueroa, Anastasia y Corral Talciani, Hernán (Eds.) Matrimonio civil y divorcio, análisis crítico y criterios para la aplicación de la Ley N 19.947, Universidad de Los Andes, Santiago, 2005, pp. 26 y 27.
} 
La definición dada por la doctrina es demasiado amplia, abarcando aspectos que no son parte integrante del menoscabo que pretende reparar el derecho a compensación económica. A nuestro parecer, la noción de cónyuge más débil sólo dice relación con el desmedro económico.

Así, para determinar quién es el cónyuge más débil, es necesario remitirse a los datos entregados por el Instituto Nacional de Estadísticas (INE) en el año 2002. Según éstos, el aporte que hombres y mujeres hacen a cada tipo de trabajo es muy diferente. Las mujeres aportan con el 35\% de la fuerza laboral mercantil, lo que significa que un $65 \%$ de ellas están dedicadas al trabajo doméstico no remunerado. Del total de personas que declararon dedicarse a las labores del hogar, el 95\% son mujeres ${ }^{16}$.

Como se puede apreciar, la preocupación del legislador, expresada en el texto del artículo $3^{\circ}$ NLMC y en las actas de la ley, e incluso en las indicaciones presentadas al proyecto de ley, está orientada a la protección de aquel cónyuge que queda en una situación de precariedad económica al término del matrimonio. Como consecuencia de estar la protección al cónyuge débil determinada por la situación económica en que éste queda, y a pesar de que la ley no distingue expresamente, ella será entregada en la mayoría de los casos a la mujer, principalmente por la desigualdad económica en que ésta queda tras haberse dedicado a las labores domésticas y haber postergado su situación laboral y económica en aras de la familia.

Llama la atención la expresión "más débil" utilizada por el legislador; quizás habría bastado con señalar "débil". Pero al revisar las actas de la ley se observa una tendencia relativa a estimar que el divorcio genera pobreza, y que ambos cónyuges se van a ver perjudicados por el quiebre matrimonial. En definitiva, tanto el hombre como la mujer sufrirán las negativas consecuencias económicas de la ruptura matrimonial y, en ese marco, uno se encuentra en una situación de desventaja respecto del otro, por tanto, desde ese punto de vista es el "más débil".

En consecuencia, a nuestro juicio, la protección del cónyuge más débil "económicamente" es una manifestación de un principio de carácter general, la equidad, que en la legislación chilena faculta al juez para corregir la desigualdad entre los cónyuges proveniente del menoscabo económico que la ruptura puede generar en un cónyuge, producto de no haber realizado actividad remunerada o lucrativa durante el matrimonio.

El principio de igualdad, garantizado por la Constitución y por los tratados internacionales ratificados por Chile y que se encuentren vigentes, obliga al

${ }^{16}$ GÓmez de LA TORRE, "Compensación económica", cit. nota n. 14, p. 5. 
legislador a crear los mecanismos jurídicos orientados a solucionar el problema de la desigualdad entre hombres y mujeres ${ }^{17}$.

La Ilustrísima Corte de Apelaciones de Rancagua, en sentencia de fecha 24 de enero de 2007, en causa Rol No 1.701-2006, señala "que en virtud de lo anterior y teniendo en especial consideración que la institución de la compensación económica, se creó por el legislador, con el propósito de proteger a la parte más débil, lo que en este caso se da por parte de la actora reconvencional, quien desde hace casi veinte años ha debido dedicarse al cuidado de un hijo con serios problemas psiquiátricos, lo que de no haberlo hecho así, hubiere importado que otras personas, presumiblemente remuneradas, lo hubieren realizado".

Como conclusión preliminar, de la historia de la ley y de las diversas instituciones que la misma establece para la protección del cónyuge débil (la denominada cláusula de dureza, la compensación económica y la aprobación del convenio regulador), se puede colegir que la NLMC protege al cónyuge que, al término del matrimonio, se encuentra en una situación de desmedro exclusivamente económico, descartando todo menoscabo proveniente de otros aspectos, como el psicológico, psiquiátrico, moral, etc., lo que resulta además plenamente coherente con el artículo 61 NLMC.

\section{Progresos de la autonomía privada en el derecho de familia}

El campo de aplicación de la autonomía privada ha tenido un avance sostenido en materias de familia. En este orden de ideas, el margen de autonomía de la voluntad de los cónyuges se amplía considerablemente, pues, por un lado, ya no están obligados a permanecer unidos para toda la vida, sino que, acreditando en juicio una de las causales de divorcio, ya sea por culpa o por cese efectivo de la convivencia, pueden poner término al vínculo conyugal. Por otro lado, en sede de separación y de divorcio se les permite a las partes regular sus relaciones mutuas y las concernientes a sus hijos, y eso sin considerar la conciliación y la mediación, como formas alternativas de resolver los conflictos de familia en sede judicial.

Este acuerdo tendiente a regular las relaciones conyugales y paterno-filiales, es exigido por el legislador para solicitar de común acuerdo la separación judicial (art. $27 \mathrm{NLMC}$ ) o el divorcio (art. 55 inc. $2^{\circ} \mathrm{NLMC}$ ). Excluimos aquellos acuerdos que pueden celebrar los cónyuges con ocasión de la separación de hecho (que más bien podríamos denominar separación convencional), y que

${ }^{17}$ En este sentido, Veloso Valenzuela, Paulina, "Algunas reflexiones sobre la compensación económi$\mathrm{ca}^{\prime}$, Revista Actualidad Jurídica, Facultad de Derecho, Universidad del Desarrollo, N 13, Santiago, 2006, p. 176. 
la NLMC los considera sólo para efectos de dar fecha cierta al cese efectivo de la convivencia entre los cónyuges.

Además de los acuerdos señalados, progresivamente nuestro legislador ha facultado a los cónyuges para decidir una serie de materias relacionadas tanto con el matrimonio como con respecto de sus hijos comunes. Sin analizar las particularidades de este tipo de negocio jurídico (lo que excede los límites de este trabajo), podemos mencionar, además del convenio regulador, otros que gradualmente se han incorporado a nuestra legislación, tales como: el reconocimiento de un hijo, la adopción, la promesa de matrimonio, las capitulaciones matrimoniales, la sustitución del régimen patrimonial del matrimonio, la liquidación de la sociedad conyugal, la determinación del crédito de participación en el régimen de participación en los gananciales, la asignación del cuidado personal y de la patria potestad, las transacciones sobre alimentos, la regulación del régimen de relación directa y regular y, por último, los pactos amistosos de separación.

Ha sido frecuente considerar que, como las relaciones jurídicas familiares escapan generalmente a la autonomía privada -o autonomía de la voluntad--, la teoría general del acto jurídico es extraña al derecho de familia. Se juzga que las relaciones familiares, y los derechos y deberes que tales relaciones determinan, no tienen por fuente la voluntad de los sujetos sino a la ley que, en cada caso, dispone los efectos de tales relaciones ${ }^{18}$.

Sin embargo, se ha sostenido que si la constitución de las relaciones familiares nace de la voluntad de las personas (la de los contrayentes en el matrimonio, la del progenitor que reconoce a un hijo, la de los adoptantes, etc.) se está frente a auténticos actos jurídicos que son la fuente de relaciones de familia ${ }^{19}$.

Para Díez-Picazo, "el poder que se reconoce a la voluntad de las partes no es consecuencia de un desinterés o de un abandono de las situaciones reguladas por parte del legislador. Lejos de ello, nos parece que se trata simplemente de reconocer que los que están más cerca de los problemas pueden regularlos mejor que otros que, distanciados, sólo podrían formular un juicio demasiado abstracto" $^{\prime 20}$.

Desde este punto de vista, planteamos que la NLMC reconoce dicho principio en el artículo 63 NLMC, dejando plena libertad a los cónyuges para

\footnotetext{
${ }^{18}$ BOSSERT, Gustavo; ZANnONI, Eduardo, Manual de derecho de familia, Editorial Astrea, Buenos Aires, sexta edición, 2007, pp. 22 y 23.

${ }^{19}$ Bossert; Zannoni, Manual, cit. n. 18, p. 23.

${ }^{20}$ Dí́z-PICAZo; PonCE de León, Luis, "La figura del convenio regulador en el marco del negocio jurídico familiar y de los principios constitucionales del derecho de familia", en Convenios reguladores de las relaciones paterno-filiales y patrimoniales en las crisis del matrimonio, Ediciones Universidad de Navarra, Navarra, segunda edición, 1989, p. 43.
} 
regular el derecho a compensación económica, monto y forma de pago. En ese contexto, la actividad del juez queda limitada a la homologación de la voluntad de las partes, las que pueden renunciar a esa compensación (incluso tácitamente), establecer el monto que estimen por ese concepto, y, desde luego, la forma de pago. En relación con esto último, incluso puede establecerse que éste se haga como una renta vitalicia, ya que las limitaciones -que analizaremos más adelante- en cuanto a que la cuantía debe corresponder a un monto único pagadero de contado o un número determinado de cuotas, no es aplicable a los cónyuges, sino sólo al juez, conforme lo dispuesto en los arts. 65 y 66 NLMC.

Sólo a modo de ejemplo, el artículo 65 NLMC señala que "en la sentencia, además, el juez determinará la forma de pago de la compensación, para lo cual podrá establecer las siguientes modalidades", de lo que se desprende que el mandato legal obliga sólo al juez.

\section{DeterminaCión Del DERECHO A COMPENSACIÓN ECONÓMICA}

En principio, la NLMC reconoce la más amplia libertad a los cónyuges para determinar el derecho a compensación económica, cuantía y forma de pago ${ }^{21}$. Así fluye de lo dispuesto en el artículo $63 \mathrm{NLMC}^{22}$, que utiliza la expresión "serán convenidos por los cónyuges"; y también de lo dispuesto en el artículo $64 \mathrm{NLMC}^{23}$, que reitera la misma idea al señalar que "a falta de acuerdo, corresponderá al juez determinar la procedencia de la compensación y fijar su monto". De lo expuesto surge como consecuencia lógica que el legislador ha establecido un verdadero orden de prelación, siendo los primeros llamados a regular este derecho los cónyuges, que están en mejor posición que el juez para resolver sus propios asuntos, lo cual resulta coherente con la lógica que impera en los tribunales de familia, en orden a privilegiar las soluciones pacíficas y colaborativas entre las partes del conflicto familiar.

De este modo, en subsidio y sólo a falta de acuerdo, debe intervenir el juez para determinar la procedencia de la prestación compensatoria, fijar su

\footnotetext{
${ }^{21}$ Cf. Lepín, La compensación, cit. n. 1, p. 136.

${ }^{22}$ Artículo 63 NLMC: "La compensación económica y su monto y forma de pago, en su caso, serán convenidos por los cónyuges, si fueren mayores de edad, mediante acuerdo que constará en escritura pública o acta de avenimiento, las cuales se someterán a la aprobación del tribunal".

${ }^{23}$ Artículo 64 NLMC: "A falta de acuerdo, corresponderá al juez determinar la procedencia de la compensación económica y fijar su monto.

Si no se solicitare en la demanda, el juez informará a los cónyuges la existencia de este derecho durante la audiencia preparatoria.

Pedida en la demanda, en escrito complementario de la demanda o en la reconvención, el juez se pronunciará sobre la procedencia de la compensación económica y su monto, en el evento de dar lugar a ella, en la sentencia de divorcio o nulidad".
} 
monto, y, aunque el artículo 64 NLMC no lo menciona, determinar su forma de pago, esto último en relación con lo dispuesto en el artículo $65 \mathrm{NLMC}^{24}$, que prescribe que "en la sentencia, además, el juez determinará la forma de pago de la compensación".

Según se señalará, los artículos 65 y 66 NLMC establecen un orden de prelación al que se debe ceñir el juez en la determinación de la forma de pago, al tiempo que le impone ciertas cargas tendientes a dar protección al cónyuge débil.

En el primer caso, esto es, cuando la determinación la realizan las partes, se deben cumplir los requisitos establecidos en el citado artículo 63, aunque se hace necesario distinguir si el divorcio ha sido solicitado unilateralmente -en cuyo caso habrá que distinguir, a su vez, si su causa es el cese de la convivencia o la culpa, cuestión que, de todas formas, tiene un interés más bien teórico que práctico, ya que resulta difícil imaginar un divorcio por culpa en que las partes pudieran arribar a un acuerdo en torno al monto de la compensación- o si se trata de un divorcio solicitado de común acuerdo por los cónyuges por haber cesado su convivencia por más de un año.

Si se trata de un divorcio unilateral, rige lo anteriormente señalado, esto es, se aplica el artículo 63, conforme con el cual pueden celebrar estos acuerdos los cónyuges mayores de edad ${ }^{25}$, debiendo dicho acuerdo constar en escritura pública o acta de avenimiento, y, además, el acuerdo debe ser aprobado por el tribunal. Estos requisitos no representan mayor dificultad, aunque luego de analizar la situación del divorcio solicitado de común acuerdo, retomaremos la idea relacionada con la aprobación judicial del acuerdo, específicamente en lo que refiere a las facultades del juez frente al convenio.

\footnotetext{
${ }^{24}$ Artículo 65 NLMC: "En la sentencia, además, el juez determinará la forma de pago de la compensación, para lo cual podrá establecer las siguientes modalidades:

1. Entrega de una suma de dinero, acciones u otros bienes. Tratándose de dinero, podrá ser enterado en una o varias cuotas reajustables, respecto de las cuales el juez fijará seguridades para su pago.

2. Constitución de derechos de usufructo, uso o habitación, respecto de bienes que sean de propiedad del cónyuge deudor. La constitución de estos derechos no perjudicará a los acreedores que el cónyuge propietario hubiere tenido a la fecha de su constitución, ni aprovechará a los acreedores que el cónyuge beneficiario tuviere en cualquier tiempo".

${ }^{25} \mathrm{Nada}$ se señala con respecto a los mayores de 16 años que pueden celebrar matrimonio de acuerdo a lo prescrito por el art. $5^{\circ} \mathrm{NLMC}$, que prescribe que no podrán contraer matrimonio: $2^{\circ}$ Los menores de dieciséis años. Se trata de menores adultos (art. 26 Código Civil), que de acuerdo al art. 1447 del Código Civil, son relativamente incapaces, sujetos por regla general a la potestad de su padre o madre o sometidos a guarda. Los actos en que intervienen pueden ser ejecutados por ellos mismos con autorización de su padre, madre o curador, según el caso, o bien ser ejecutados directamente por sus representantes legales. Cf. Ducci Claro, Carlos, Derecho Civil. Parte general, Editorial Jurídica de Chile, Santiago, cuarta edición, 2009, p. 286. Se ha señalado que la incapacidad generalmente no alcanza los actos de familia, y en este caso, pueden contraer matrimonio, pero no podrían sin autorización pactar una compensación económica.
} 
El otro caso -esto es, el del divorcio de común acuerdo- obliga a referirse a la determinación de la compensación económica en el acuerdo completo y suficiente, denominado por los españoles "convenio regulador" ${ }^{26}$. Recordemos que el artículo 55 NLMC permite a los cónyuges solicitar de común acuerdo el divorcio, siempre que acrediten un plazo de cese de convivencia durante un lapso mayor de un año, y acompañen un acuerdo que regule en forma completa y suficiente sus relaciones mutuas y con respecto a sus hijos.

En primer lugar, aunque la ley no lo señala, es necesario que el convenio regulador conste por escrito, a lo menos por escritura privada (incluso no existe a nuestro juicio inconveniente en que se incorpore en un otrosí del escrito de la demanda o solicitud de divorcio), ya que el artículo 55 señala en forma imperativa que "debe acompañarse" (la única forma es que conste por escrito), quedando, en consecuencia, como un requisito de la acción de divorcio de común acuerdo $\mathrm{o}$, si se quiere, como una carga para las partes, ya que en la práctica los cónyuges pueden estar de acuerdo en el divorcio, pero no necesariamente lo estarán en las otras materias de familia que deben regular en el convenio.

Dicho acuerdo será completo si regula todas y cada una de las materias indicadas en el artículo 21 NLMC, es decir, las que dicen relación con las relaciones mutuas entre los cónyuges, a saber: a) los alimentos que se deban ${ }^{27}$; b) las materias vinculadas al régimen de bienes del matrimonio, es decir, la liquidación de la sociedad conyugal o la determinación del crédito de participación, esto último en el régimen de participación en los gananciales.

El artículo 21, también agrega que se debe regular respecto de los hijos: a) el cuidado personal; b) la pensión de alimentos, y c) el régimen comunicacional o de relación directa y regular del padre que no tiene la custodia de los hijos.

Todo lo anterior es lo que se denomina en el derecho español el contenido mínimo u obligatorio del convenio regulador, es decir, se trata de aquellas materias que se deben regular en forma obligatoria ${ }^{28}$.

Como se puede apreciar, la ley no obliga a regular el derecho a compensación económica. Sin embargo, algunos podrían pensar que igualmente se debería

\footnotetext{
${ }^{26}$ Arts. 81, 86 y 90 del Código Civil Español.

${ }^{27}$ Debemos entender las deudas por pensiones alimentarias devengadas, ya que en virtud de lo dispuesto por el art. $60 \mathrm{NLMC}$, "el divorcio pone fin a las obligaciones y derechos de carácter patrimonial cuya titularidad y ejercicio se fundan en la existencia del matrimonio, como los derechos sucesorios recíprocos y el derecho de alimentos", en consecuencia, no se puede regular una pensión de alimentos para el ex cónyuge.

${ }^{28}$ Cf. VVAA, "Convenios reguladores de las relaciones paterno-filiales y patrimoniales en las crisis del matrimonio", Navarra, Ediciones Universidad de Navarra, segunda edición, 1989. Y CORDERO CUTILLAS, Iciar, El convenio regulador en las crisis matrimoniales (estudio jurisprudencial), Editorial Aranzandi, Navarra, 2004.
} 
determinar su forma y procedencia en forma obligatoria (en forma voluntaria no se ve inconveniente), atendidos los criterios de suficiencia que establece el artículo 55, que señala que se entenderá que el acuerdo es suficiente "si resguarda el interés superior de los hijos, procura aminorar el menoscabo económico que pudo generar la ruptura y establece relaciones equitativas, hacia el futuro, entre los cónyuges cuyo divorcio se solicita".

Respecto de lo anterior, cabe tener presente las siguientes consideraciones. En primer lugar, estos criterios deben aplicarse al contenido mínimo u obligatorio, es decir, el juez debe determinar si las materias reguladas cumplen convenientemente con el interés superior de los hijos y protege al cónyuge débil, pero no se trata de exigencias adicionales en cuanto a las materias que se deben regular. En segundo lugar, dicha norma es idéntica a la del artículo 27 NLMC, que señala cuándo un acuerdo es completo y suficiente en sede de separación judicial, por lo que, de aceptar la teoría que sostiene que es suficiente cuando regula la compensación económica, implicaría la obligación de regular una compensación en la separación judicial ${ }^{29}$, en circunstancias que la compensación no procede en estos casos.

Por último, es necesario plantear cuál es el grado de intervención del juez en los acuerdos antes señalados, esto es, si se debe limitar a homologar la voluntad de las partes, o si puede modificar o completar el convenio regulador.

Tratándose de un acuerdo en un juicio de divorcio que ha sido solicitado en forma unilateral, pareciera que las facultades son de simple homologación, de acuerdo a lo prescrito en el artículo 63 NLMC.

La interpretación de estos casos dependerá de la visión que cada uno tenga sobre la naturaleza de la prestación compensatoria. En este sentido, si la visión del derecho a compensación es asistencial, se refutará señalando que las facultades del juez no se limitan a la mera homologación, ya que por aplicación del principio de protección al cónyuge más débil el juez debe intervenir incluso modificando o complementando el acuerdo, aplicando por analogía el artículo $31 \mathrm{NLMC}^{30}$, norma esta que autoriza al juez en la sentencia a "subsanar sus

\footnotetext{
${ }^{29}$ Sobre el particular ver Lepín, La compensación, cit. n. 1, pp. 104 y ss.

${ }^{30}$ Artículo 31 NLMC: "Al declarar la separación, el juez deberá resolver todas y cada una de las materias que se señalan en el artículo 21, a menos que ya se encontraren reguladas o no procediere la regulación judicial de alguna de ellas, lo que indicará expresamente. Tendrá en especial consideración los criterios de suficiencia señalados en el artículo 27.

El juez utilizará los mismos criterios al evaluar el acuerdo presentado o alcanzado por los cónyuges, procediendo en la sentencia a subsanar sus deficiencias o modificarlo si fuere incompleto o insuficiente.
}

En la sentencia el juez, además, liquidará el régimen matrimonial que hubiere existido entre los cónyuges, si así se le hubiere solicitado y se hubiere rendido la prueba necesaria para tal efecto". 
deficiencias o modificarlo si fuere incompleto o insuficiente"; y, además, por aplicación del principio de actuación de oficio que inspira los procedimientos que se desarrollan ante los tribunales de familia ${ }^{31}$.

No compartimos dicho criterio, ya que resulta por lo menos dudosa la aplicación por analogía del citado artículo 31, toda vez que esta norma sólo puede aplicarse a la separación judicial. Además, existen razones que justifican la aplicación exclusiva de este precepto en esta materia, una de las cuales es la subsistencia del matrimonio.

Por otro lado, la autorización para que intervenga el juez cobra importancia cuando no se ha regulado el denominado contenido mínimo, es decir, cuando el acuerdo es incompleto, o cuando, habiéndose regulado todas las materias del artículo 21 NLMC, no se compadecen con los criterios de suficiencia ya descritos.

Otro argumento en contra es la existencia de cierto consenso en que los cónyuges pueden renunciar al derecho a compensación, por lo menos en el marco del juicio de divorcio. Incluso se acepta la renuncia tácita al no ejercer el derecho en la oportunidad procesal pertinente, por lo que si un cónyuge -el supuesto "débil"- puede renunciar al derecho, puede, por tanto, regular la prestación en los términos que estime pertinente, como argumento a fortiori "quien puede lo más puede lo menos".

Finalmente, por una razón de orden práctico, si el juez no ha recibido prueba sobre la compensación, si no dispone de ningún antecedente: ¿cómo puede ponderar quién es el más débil?, ¿cómo puede analizar si el acuerdo protege suficientemente al más débil?, ¿cómo podría estar en condiciones de establecer garantías o seguridades para el pago de las cuotas?

Como conclusión preliminar, las facultades del juez para modificar o subsanar las deficiencias de los acuerdos sobre compensación económica son más restringidas, y se reducen a aprobar o rechazar el acuerdo sin poder alterar su contenido.

\section{Forma DE PAGO DE LA COMPENSACIÓN ECONÓMICA}

A continuación revisaremos las distintas formas de pago de la compensación, sancionadas por la NLMC, consignando algunos aspectos generales, para luego analizar cada una de las formas propuestas por el legislador.

\footnotetext{
${ }^{31}$ Cf. Vidal Olivares, Álvaro, "Formas de pago y la protección del derecho a la compensación económica por divorcio o nulidad", Revista Chilena de Derecho Privado, № 12, julio 2009, p. 71; CoRRAL TALCIANI, Hernán, "La compensación económica en el divorcio y la nulidad matrimonial", Revista Chilena de Derecho, Vol. 34, №1, Santiago, 2007, p. 37 y Domínguez Hidalgo, Carmen, "El convenio regulador y la compensación económica: una visión de conjunto", En Assimakópulos FiguerOA, Anastasia; CORRAL TALCIANI, Hernán (Eds.) Matrimonio civil y divorcio, análisis crítico y criterios para la aplicación de la Ley N 19.947, Universidad de Los Andes, Santiago, 2005, p. 100.
} 


\section{Aspectos generales. Orden de prelación}

La ley reserva, en primer lugar, la posibilidad de regular la compensación económica a las partes, y, en subsidio, es decir, "a falta de acuerdo", será el juez quien regule su procedencia y fije "su monto". Esto último nos lleva a concluir que, al igual como ocurre en Francia, el pago debe realizarse en una sola cuota, o más bien, en una prestación única o de una sola vez ${ }^{32}$. Normalmente, se estipulará que el pago se haga mediante una suma de dinero, la que podrá ser enterada en una o varias cuotas.

Esta situación se discutió durante la tramitación de la ley N 19.947, prevaleciendo en el debate legislativo la idea de terminar con el conflicto entre los cónyuges, por lo menos en el plano económico, al fijar una suma única que no admite revisión posterior, con lo que se evita la presentación de demandas de rebaja o aumento de la cantidad regulada por el juez a título de compensación económica ${ }^{33}$.

Es decir, la regla general que debe utilizar el juez es el pago en una prestación única, y excepcionalmente (en términos teóricos, ya que, en la práctica, es lo más usual), en un número reducido de cuotas reajustables, respecto de las cuales el juez "debe" fijar seguridades para su pago, la entrega de acciones u otros bienes, o constituir derechos de usufructo, uso o habitación, respecto de bienes que sean de propiedad del deudor (art. 65 NLMC).

Sólo en el evento que no sea posible aplicar una de las modalidades anteriores dado que el deudor no tiene la capacidad económica para solucionar de esa forma su monto, el juez "podrá" dividir el monto en cuantas cuotas fuere necesario, considerando al efecto, la capacidad económica del cónyuge deudor, y expresará el valor de cada cuota en una unidad reajustable. La cuota respectiva se considerará alimentos para efectos de su cumplimiento, a menos que se ofrezcan otras garantías para ello (art. 66 NLMC).

$\mathrm{Al}$ revisar la jurisprudencia ${ }^{34}$ no queda claro si el pago en cuotas se debe a la aplicación del artículo 65 ó 66 NLMC, ya que no existe referencia que fundamente la aplicación de dicha modalidad y porque tampoco se establecen seguridades para el pago de las cuotas.

\footnotetext{
${ }^{32}$ Así, por ejemplo, el art. 273 del Código Civil francés señala que "La prestación compensatoria tendrá un carácter a tanto alzado". En: http://www.legifrance.gouv.fr [visitado el 20/10/2011]. De igual forma PizarRo Wilson, Carlos; Vidal Olivares, Álvaro, La compensación económica por divorcio o nulidad de matrimonio, Editorial LegalPublishing, Santiago, 2009, p. 99, y Veloso, "Algunas reflexiones", cit. n. 17, p. 185.

${ }_{33}$ Boletín del Senado № 1.759-18, cit. n. 3, pp. 587 a 605. En similar sentido, Domínguez, "Compensación económica", cit. n. 12, p. 5, y PIZARRO; VIDAL, La compensación económica, cit. n. 32, p. 97.

${ }^{34}$ La revisión de la jurisprudencia corresponde a 15 sentencias de la Corte Suprema y 37 de las diversas Cortes de Apelaciones, datos disponibles en jurisprudencia citada al final de este texto.
} 
La situación descrita es la que justifica la revisión de las normas en comento, dado que al no cumplir con lo establecido en ellas se van a generar serias dificultades al momento de solicitar el cumplimiento o, específicamente, al solicitar la aplicación de apremios, ya que la asimilación que establece el legislador de las cuotas a los alimentos sólo procede en el caso del artículo 66 y no en los casos del artículo 65. Situación que el legislador pretende evitar al señalar que el juez "fijará" seguridades para su pago.

Todas las formas o modalidades de pago establecidas en la NLMC deben entenderse en el sentido de procurar poner término al conflicto económico entre los cónyuges y, por otro lado, procurar proteger los intereses del cónyuge más débil, lo que queda de manifiesto por la carga impuesta al juez de fijar cuotas en una unidad reajustable y establecer seguridades para el pago, sin perjuicio de lo dispuesto en el artículo $3^{\circ}$, que establece que las materias reguladas por la NLMC deberán ser resueltas cuidando proteger siempre el interés superior de los hijos y del cónyuge más débil.

En ese sentido, se ha señalado que "el legislador no protege directamente al derecho, sino que asigna al juez de familia la tarea de dotarlo de una protección, según sean las particulares circunstancias del caso, y que se concreta en la forma de pago de la obligación correlativa de la compensación, que debe ajustarse al marco legal de los artículos 65 y 66 de la LMC" 35 .

Otra modalidad de pago, es la regulada en el artículo 80 de la Ley № 20.255 que establece la Reforma Previsional, y que permite al juez ordenar el traspaso de los fondos de la cuenta de capitalización individual del cónyuge deudor a la cuenta del cónyuge beneficiario.

Sin perjuicio de la enumeración precedente, estimamos que el juez puede establecer otras modalidades de pago, pues no hay una enumeración taxativa, una vez que se verifique la imposibilidad de aplicar alguna de las modalidades anteriores y que dicha aplicación se fundamente en la protección del cónyuge más débil. En este sentido, el artículo 65 NLMC señala "el juez determinará la forma de pago de la compensación, para lo cual podrá establecer las siguientes modalidades", y el citado artículo 80 de la ley $N^{\circ} 20.255$, regula otra modalidad de pago de la compensación.

En conclusión, la ley establece un orden de prelación para determinar la forma de pago, siempre que sea decretada por el juez, siendo la regla general la prestación única pagadera de una sola vez y, en subsidio, si no es posible regularlo de esa forma, se podrá establecer la entrega de una suma de dinero, acciones u otros bienes o la constitución de derechos reales de goce sobre bienes de propiedad del deudor, y sólo en caso de insolvencia, fijar el número de cuotas necesarias.

${ }^{35}$ PIZARro; VIDAL, La compensación económica, cit. n. 32, p. 95. 
De no ser posible aplicar las modalidades anteriores puede el juez establecer otra modalidad de pago. Consideramos, además, que en todos los casos señalados se podrá también ordenar el traspaso de fondos de pensiones, de acuerdo al artículo 80 de la ley $\mathrm{N}^{\circ} 20.255$, en forma conjunta o subsidiaria.

Este orden de prelación se sustenta en la finalidad establecida por el legislador, en el sentido de que se pague en un solo acto, a fin de evitar posteriores conflictos patrimoniales entre los ex cónyuges, y de la protección al cónyuge más débil, norma orientadora para el juez, quedando obligado por las exigencias o cargas que le imponen los artículos 65 y 66.

\section{Formas de pago en particular}

\subsection{En una sola "cuota" o cantidad única pagadera de contado}

Es la regla general establecida por el legislador, como ya se ha expresado, con la finalidad de poner término al conflicto conyugal y eliminando la posibilidad de nuevos juicios con solicitudes de aumento, de rebaja o de cese de la prestación.

De esta forma lo ha expresado Álvaro Vidal, que sostiene que "la finalidad perseguida por la LMC, así fluye de la historia de su establecimiento, es que el conflicto entre los cónyuges en lo patrimonial se resuelva de una sola vez, o en el menor tiempo posible, lo que se ve reflejado en el marco legal sobre la forma de entrega que pasa desde la consignación de un monto o de una pensión compensatoria por un plazo máximo de cinco años (artículo 38 de la indicación del Presidente de la República) a una suma única que puede dividirse en cuotas siempre que el deudor ofrezca seguridades para el cumplimiento suficiente (actual artículo 65 de la LMC) (136. $^{\prime 36}$.

Continúa el mismo autor señalando que "se quiere evitar la perpetuación del conflicto entre los cónyuges o que con ocasión del pago de la compensación surjan otros que pudieran afectar el interés de los hijos comunes. Tal objetivo se alcanza idealmente mediante la entrega de una suma alzada, única, global e inmodificable, pagadera de contado o, cuando mucho, dividida en un reducido número de cuotas" ${ }^{\prime 37}$.

En similar sentido Carmen Domínguez señala que "la firme intención del legislador es querer concentrar la determinación de la cuestión económica en un solo momento. Por lo mismo, razona sobre la idea que el monto de la compensación debe ser fijado en la sentencia y en una suma única y total que no admite revisión futura. Esto resulta ostensible de su regulación, pero también de la historia fidedigna en el Senado, de cuyo debate se puede colegir que el esfuerzo permanente de quienes más intervinieron fue evitar que las cuestiones económicas

\footnotetext{
${ }^{36}$ VIDAL, "Formas de pago", cit. n. 31, p. 72.

${ }^{37}$ VIDAL, "Formas de pago", cit. n. 31, p. 73.
} 
dieran lugar a conflictos permanentes entre los ex cónyuges. Incluso se llegó a fundar esta forma de fijación de la compensación en que las personas de menores recursos 'también tiene derecho a reconstruir su familia y vivir en paz' sin que deban estar obligados a tener que destinar el mayor porcentaje de su sueldo a la mantención de la familia antigua y no a sostener la familia nueva" ${ }^{\prime 38}$.

A la misma conclusión ha llegado nuestra jurisprudencia, la Excelentísima Corte Suprema, en la sentencia de 20 de diciembre de 2006, causa Rol № 3.4952006, expresa "que, como regla general, la compensación será pagada de una sola vez y, por excepción, según lo dispuesto en el artículo 66 de la Ley de Matrimonio Civil, el legislador autoriza su pago en cuotas. Por consiguiente, no puede sino concluirse que aun cuando la legislación entrega amplia libertad al juez para fijar la forma de pago de la compensación, sea como capital en suma única, bajo las modalidades que establece el artículo 65 de la misma ley o en cuotas periódicas con una duración determinada, su monto siempre debe ser fijado en la sentencia y la forma de enterarlo variarán de acuerdo al mérito del proceso". En el mismo sentido la sentencia de fecha de 29 de julio de 2009, en causa Rol № 3.911-2009 señala que "de relacionar los artículos 63, 64, 65 y 66 de la Ley N 19.947, se infiere que el legislador ordena pagar un monto determinado invariable en el tiempo, cualesquiera sean las circunstancias personales y patrimoniales de los interesados -deudor o acreedor- posteriores a la sentencia que la regula". Y también la llustrísima Corte de Apelaciones de Concepción, en la sentencia de fecha 24 de febrero de 2009, en causa Rol № 1.707-2008, expresa que "la compensación económica será pagada de una sola vez, y, por excepción, según lo dispuesto en el artículo 66 de la ley de Matrimonio Civil, el legislador autoriza su pago en cuotas (sentencia citada). Atendido la situación patrimonial del demandado y la facultad concedida en el artículo 66 recién citado, se mantendrá el pago en cuotas determinado por la sentenciadora de primer grado".

\subsection{En un número reducido de cuotas. Caso del artículo 65 NLMC}

En el caso del pago en cuotas, la regla general será el menor número de ellas $^{39}$, atendida la finalidad del legislador, y además, se faculta al juez para fijar cualquier forma de reajuste. La experiencia en los tribunales de familia en materia de pensiones alimenticias considera el alza que experimente el Índice de Precios al Consumidor (IPC), que fija el Instituto Nacional de Estadísticas

\footnotetext{
${ }^{38}$ Domínguez, "Compensación económica", cit. n. 12, pp. 5 y 6.

${ }^{39}$ En el derecho francés se limita el pago en cuotas a un período de 8 años, como se desprende del inciso $1^{\circ}$ del art. 275 del Código Civil, que señala que "cuando el deudor no tuviera capacidad de pagar el capital en las condiciones previstas en el artículo 274, el Juez fijará las modalidades de pago del capital, con el límite de ocho años, bajo forma de pagos periódicos indizados conforme a las reglas aplicables a las pensiones alimenticias".
} 
(INE), o un porcentaje del ingreso mínimo remuneracional (que se reajusta por ley una vez al año), o también expresar el monto en unidades de fomento (UF) o unidades tributarias mensuales $(\mathrm{UTM})^{40}$. Lo esencial es que el dinero mantenga su valor y, por tanto, el mismo poder adquisitivo.

Lo trascedente es la carga que el legislador impone al juez de fijar seguridades para su pago, lo que se materializa, tratándose de la protección del cónyuge más débil, en establecer cauciones reales o personales. Lo natural será una hipoteca o una prenda en términos similares a los del artículo 10 de la Ley $\mathrm{N}^{\circ} 14.908$ sobre Abandono de Familia y Pago de Pensiones Alimenticias ${ }^{41}$.

Como ocurre en la legislación francesa, que permite que el pago en capital o cuotas quede a resguardo mediante el establecimiento de una garantía como la constitución de una hipoteca, prenda, fianza u otro contrato ${ }^{42}$.

La profesora Susan Turner ha planteado las dudas interpretativas que genera la expresión "seguridades para el pago", señalando que "si se entendiere en un sentido amplio, quedaría comprendida tanto la constitución de cauciones, reales o personales, asociadas a la obligación alimenticia por parte del cónyuge deudor de la compensación económica como las modalidades tendientes a asegurar el pago, como la retención por parte del empleador de una cuota de la remuneración del cónyuge deudor. En un sentido restringido, sólo se referiría a la rendición de cauciones por parte del deudor ${ }^{43}$.

\footnotetext{
${ }^{40}$ Lepín, La compensación económica, cit. n. 1, p. 145.

${ }^{41}$ Artículo 10 ley N 14.908: "El juez podrá también ordenar que el deudor garantice el cumplimiento de la obligación alimenticia con una hipoteca o prenda sobre bienes del alimentante o con otra forma de caución.

Lo ordenará especialmente si hubiere motivo fundado para estimar que el alimentante se ausentará del país. Mientras no rinda la caución ordenada, que deberá considerar el periodo estimado de ausencia, el juez decretará el arraigo del alimentante, el que quedará sin efecto por la constitución de la caución, debiendo el juez comunicar este hecho de inmediato a la misma autoridad policial a quien impartió la orden, sin más trámite".
}

${ }^{42}$ Art. 274 Código Civil francés: "El Juez decidirá las modalidades según las cuales se ejecutará la prestación compensatoria entre las formas siguientes:

$1^{\circ}$ Pago de una cantidad de dinero, pudiendo quedar subordinado el pronunciamiento del divorcio a la constitución de las garantías previstas en el artículo 277.

$2^{\circ}$ Atribución de bienes en propiedad, o de un derecho temporal o vitalicio de uso, de vivienda o de usufructo, actuando la sentencia como una cesión forzosa a favor del acreedor. Sin embargo se exigirá el acuerdo del cónyuge deudor para la atribución en propiedad de bienes que él haya recibido por herencia o donación".

Artículo 277 Código Civil francés: "Independientemente de la hipoteca legal o judicial, el Juez podrá imponer al esposo deudor que constituya una prenda, que preste fianza o que suscriba un contrato garantizando el pago de la renta o del capital".

${ }^{43}$ Turner Saelzer, Susan, "Cauciones en el derecho de alimentos y en el derecho del matrimonio chilenos", en Estudios sobre las garantías reales y personales, en homenaje a Manuel Somarriva Undurraga, T. II, editorial Jurídica de Chile, Santiago, 2008, p. 719. 
Según Vidal, la expresión "seguridades para el pago" que emplea el legislador, comprende no sólo las garantías y cauciones, constitutivas de mecanismos de protección del derecho de crédito al ensanchar el derecho de garantía general del acreedor, sino todos aquellos mecanismos o medidas que den certeza al acreedor del pago, evitando o previniendo el incumplimiento o la insatisfacción definitiva del crédito. Por lo tanto, constituyen seguridades para el pago, todas las cauciones -personales o reales-; cualquiera modalidad de garantías bancarías, los seguros de responsabilidad, las cláusulas de aceleración, la prohibición de enajenar, la retención judicial o descuento de un porcentaje de remuneraciones por parte del empleador. Tan amplia es la noción de seguridades para el pago que pudiere entenderse incluida en ella la modalidad especial que prevé la ley $N^{\circ} 20.255$ que contempla el traspaso de fondos de capitalización obligatoria hasta el límite del 50 \% existente del cónyuge deudor, con independencia del régimen patrimonial del matrimonio" 44 .

En el caso de la cláusula de aceleración, si bien constituye una garantía, en la práctica, si el deudor no paga una cuota, será más difícil que pague el total. No obstante ello, reconocemos el carácter persuasivo de dicha cláusula.

Con respecto al traspaso de fondos previsionales, se trata más bien de otra modalidad de pago y no de una seguridad para el pago, ya que lo que opera es el traspaso de una cuenta de capitalización individual a otra, y en ningún caso se transforma en una garantía.

Finalmente, como señala la profesora Turner "la constitución de las seguridades para el pago de la compensación económica no es facultativa para el juez. Los términos de la norma del artículo $65 \mathrm{~N}^{\circ} 1 \mathrm{LMC}$ son perentorios: el juez de familia deberá fijarlas" ${ }^{\prime 4}$.

\subsection{Entrega de bienes determinados. Dación en pago}

El mismo artículo 65 NLMC permite al juez fijar como forma de pago la entrega de acciones u otros bienes de propiedad del deudor, operando la transferencia del dominio del deudor al acreedor (beneficiario de la compensación). Se trata, en definitiva, de una dación en pago de especies determinadas o acciones.

Álvaro Vidal ha planteado que existe una laguna legal en esta materia al no prever la posibilidad de evicción posterior de la especie o acciones dadas ni menos que se dé una respuesta acerca de la suerte que correrá el derecho una vez producida la evicción. De igual forma, resulta interesante la solución propuesta en orden a aplicar por analogía el artículo 1792-22 del Código Civil,

\footnotetext{
${ }^{44}$ VIDAL, "Formas de pago", cit. n. 31, pp. 79 y 80.

45 Turner, "Cauciones en el derecho de alimentos y en el derecho del matrimonio chilenos", cita n. 43, p. 719.
} 
que en el régimen de participación en los gananciales dispone que de producirse la evicción de la cosa dada en pago por el crédito de participación, renace el crédito $^{46}$. Más bien sería interesante incorporar una norma similar en futuras modificaciones a la Nueva Ley de Matrimonio Civil.

Puede ocurrir que se pague a título de compensación al cónyuge beneficiario, mediante la transferencia de bienes determinados de propiedad del deudor, por ejemplo la vivienda familiar u otro bien raíz, o también un porcentaje de ella, como es el caso de los bienes de propiedad de la sociedad conyugal, que al término del matrimonio se dividirá en partes iguales entre los cónyuges. En este caso, especial cuidado se debe tener con las propiedades adquiridas a través de un mutuo hipotecario, ya que, además de las dificultades propias de la novación por cambio de deudor (difícilmente el cónyuge débil va a tener medios para asumir el crédito), puede suceder que el deudor se obligue a continuar pagando la deuda, lo que, de no suceder, va a generar el problema de los apremios, máxime si el pago consiste en la transferencia del bien, y no un número determinado de cuotas en los términos de los artículos 65 y 66 .

De igual manera, resulta importante tomar los resguardos necesarios no sólo con respecto a la cosa dada en pago, sino también, con respecto a la cosa que pueda servir de garantía, por ejemplo, la propiedad hipotecada, ya que puede ocurrir que ésta se deba enajenar por la acción de los acreedores del deudor.

\subsection{Constitución de derechos reales a favor del cónyuge beneficiario}

Conforme a lo expuesto, podemos observar que la modalidad de pago mediante la constitución de derechos reales de goce se refiere a los derechos de usufructo, uso o habitación sobre bienes de propiedad del deudor.

Sin lugar a dudas, esta modalidad de pago puede acrecentar la confusión existente sobre la naturaleza jurídica del derecho a compensación económica, en especial si se considera que tanto los derechos de usufructo, uso o habitación procuran a una persona un sustentamiento ${ }^{47}$.

De la misma forma lo han entendido Pizarro y Vidal, que señalan que "esta forma de pago no se condice mucho con la naturaleza jurídica puesto que la aproxima más a la idea de los alimentos debidos por ley" 48 .

Independiente de lo razonable de la crítica formulada, esta modalidad de pago no es algo excepcional, ya que existe en otras legislaciones, principalmente en las que sirvieron de referente a nuestro legislador, es decir, Francia y España.

\footnotetext{
${ }^{46}$ VIDAL, "Formas de pago", cit. n. 31, pp. 88 y 89.

${ }^{47}$ Alessandri Rodrícuez, Arturo; Somarriva Undurraga, Manuel, Tratado de los Derechos Reales, T. II, Editorial Jurídica de Chile, Santiago, quinta edición, 1993, p. 126.

${ }^{48}$ Pizarro; Vidal, La compensación económica, cit. n. 32, p. 101.
} 
En el Código Civil francés, el artículo 274 faculta al juez para fijar la modalidad de pago de la prestación compensatoria, ya sea mediante el pago de una cantidad de dinero o mediante la atribución en propiedad de bienes o la constitución de derechos de usufructo, uso o habitación, de carácter temporal o vitalicio ${ }^{49}$.

En España, el artículo 97 del Código Civil señala que la compensación podrá consistir en una pensión temporal o por tiempo indefinido o en una prestación única. No obstante, permite en el artículo 99 del mismo Código, la sustitución de la pensión fijada judicialmente por la constitución de una renta vitalicia, el usufructo de determinados bienes o la entrega de un capital en bienes o en dinero.

Esta situación plantea, además, el eventual vínculo que se puede generar con derechos ya existentes a otros títulos como son los derechos de usufructo, uso o habitación constituidos en una causa de alimentos (art. $9^{\circ}$ inc. $2^{\circ}$ Ley $N^{\circ} 14.908$ sobre Abandono de Familia y Pago de Pensiones Alimenticias) o en la declaración de un bien familiar (art. 147 Código Civil).

Evidentemente, el paso o tránsito de un derecho a otro, es decir, de alimentos o bien familiar a compensación económica, reforzaría los problemas concernientes a la naturaleza jurídica de esta institución ${ }^{50}$.

Se debe considerar que el artículo 60 NLMC pone término a las obligaciones y derechos de carácter patrimonial entre los cónyuges, cuya titularidad y ejercicio se fundan en la existencia del matrimonio. Por lo que dicho efecto extintivo de este conjunto de derechos pone fin a los derechos de alimentos y a la declaración de bien familiar. Aunque en este último caso existe discrepancia entre los distintos autores y también en la jurisprudencia ${ }^{51}$.

En la práctica, se debe alzar el derecho real constituido a título de alimentos o de bien familiar, para luego constituir el derecho de usufructo, uso o habitación a título de compensación económica.

A diferencia de la regulación sobre la constitución de los derechos reales señalados en materia de alimentos o de bien familiar, el legislador fue bas-

\footnotetext{
${ }^{49}$ Código Civil francés art. 274: "El Juez decidirá las modalidades según las cuales se ejecutará la prestación compensatoria entre las formas siguientes:

$1^{\circ}$ Pago de una cantidad de dinero, pudiendo quedar subordinado el pronunciamiento del divorcio a la constitución de las garantías previstas en el artículo 277.

$2^{\circ}$ Atribución de bienes en propiedad, o de un derecho temporal o vitalicio de uso, de vivienda o de usufructo, actuando la sentencia como una cesión forzosa a favor del acreedor. Sin embargo se exigirá el acuerdo del cónyuge deudor para la atribución en propiedad de bienes que él haya recibido por herencia o donación".

${ }^{50}$ PIZARRO; VIDAL, La compensación económica, cit. n. 32, p. 101.

${ }^{51}$ Cf. Troncoso Larronde, Hernán, "El divorcio como causal de desafectación de un bien declarado familiar. Comentario a un fallo reciente", en Estudios de Derecho Civil V, Jornadas Nacionales de Derecho Civil, Concepción 2009, Editorial LegalPublishing, Santiago, 2010, pp. 383 a 390.
} 
tante más parco, señalando solamente que el juez podrá constituir derechos de usufructo, uso o habitación, respecto de bienes que sean de propiedad del cónyuge deudor.

En efecto, nada se señala sobre la forma de constitución de estos derechos, a diferencia de lo que ocurre en el artículo $9^{\circ}$ inciso $2^{\circ}$ de la ley $\mathrm{N}^{\circ} 14.908$ que señala que la resolución judicial servirá de título para inscribir los derechos reales. En sentido similar, el Código Civil en el artículo 147 inciso $3^{\circ}$ señala que "la declaración judicial a que se refiere el inciso anterior servirá como título para todos los efectos legales". En este caso, es conveniente aplicar la misma fórmula.

Resulta interesante mencionar lo consignado en el artículo $9^{\circ}$ de la ley $N^{\circ} 14.908$ que señala que el juez puede fijar o aprobar que "se impute" total o parcialmente a un derecho de usufructo. Esta alternativa es señalada por Pizarro y Vidal en el sentido que "en el caso de que el juez o las partes fijen esta forma de pago, conviene considerar la necesidad de cuantificar previamente la compensación y después imputar el derecho real al monto resultante, lo que necesariamente implica limitar su vigencia en el tiempo" ${ }^{\prime 52}$.

Así lo expresa Vodanovic, a propósito de cuantificar el usufructo, en este caso para no exceder el $50 \%$ de los ingresos del alimentante en las pensiones de alimentos, que expresa que "en el caso en que el derecho de usufructo se otorga como pensión de alimenticia, debe señalarse un valor correlativo. Esto a fin de que pueda establecerse la relación con el monto de los emolumentos del deudor alimenticio y de este modo fijar la pensión alimenticia hasta una suma que no sobrepase el cincuenta por ciento de las rentas del alimentante" ${ }^{\prime 53}$.

Esta alternativa soluciona el problema de poder obtener el cumplimiento y aplicar los apremios de la ley $\mathrm{N}^{\circ} 14.908$, es decir, arresto, arraigo, retención de impuestos y suspensión de licencia de conducir. Sin embargo, resulta dudosa la aplicación del arresto por deudas de compensación económica que, por no tener naturaleza alimenticia, no quedarían amparadas por el art. $7^{\circ}$ del Pacto de San José de Costa Rica ${ }^{54}$.

\footnotetext{
52 Pizarro; Vidal, La compensación económica, cit. n. 32, p. 101.

${ }^{53}$ Vodanovic Haklicka, Antonio, Derecho de alimentos, Editorial LexisNexis, Santiago, cuarta edición, 2004, p. 123.

${ }^{54}$ En este sentido, sentencia de fecha 26 de julio de 2011, causa Rol № 683-2011, de la llustrísima Corte de Apelaciones de Temuco, que señala que "de acuerdo con lo dispuesto en este tratado, el rechazo de la prisión por deudas constituye un derecho humano que se ha estatuido con carácter de regla general. La excepción a la misma se refiere, precisamente, a las deudas derivadas del incumplimiento de deberes alimentarios (excepción que en cuanto tal debe ser interpretada y aplicada restrictivamente). Y, según se ha visto, la compensación económica no presenta dicho carácter. Por lo mismo, decretar el arresto en caso de incumplimiento del pago de la compensación económica importa aplicar una prisión por deuda, la que se encuentra expresamente prohibida por el Derecho internacional al que se encuentra vinculado el Estado de Chile".
} 
Tampoco la ley establece una prohibición de enajenar o gravar como la establecida en el artículo $9^{\circ}$ de ley $N^{\circ} 14.908$ que agrega en lo pertinente que "si se tratare de un bien raíz, la resolución judicial servirá de título para inscribir los derechos reales y la prohibición de enajenar o gravar en los registros correspondientes del Conservador de Bienes Raíces. Podrá requerir estas inscripciones el propio alimentario".

Existiendo una prohibición inscrita no se puede enajenar el bien, lo que sin duda constituye una especial protección, que permite hacer efectivo el derecho, ya que, no obstante tratarse de un derecho real, el evitar actos de disposición sobre esos bienes justifican incluir una norma de este tipo en la compensación a efectos de proteger al cónyuge más débil.

Lo que puede ocurrir en la práctica es que la propiedad se encuentre hipotecada, lo que en principio no impide la constitución del derecho real. En sentido contrario se ha sostenido que el deudor hipotecario no puede hacer nada que vaya en detrimento de la integridad de la garantía otorgada ${ }^{55}$.

Sin embargo, para la mayoría de la doctrina y la jurisprudencia el usufructo constituido con posterioridad a una hipoteca, no afecta a ésta, por lo que el acreedor hipotecario sólo puede solicitar la inoponibilidad del usufructo en el momento que vea amagado su derecho. En consecuencia, si el deudor cumple su obligación no será necesario subastar la propiedad hipotecada ni remover el usufructo ${ }^{56}$.

Por otra parte, nada dice la NLMC sobre las obligaciones del usufructuario de rendir caución de conservación y restitución y de confeccionar inventario solemne (art. 775 Código Civil), o en los derechos de uso o habitación de confeccionar inventario de los bienes sobre los que recae su derecho (art. 813 Código Civil). A diferencia de lo que ocurre en la ley $N^{\circ} 14.908$, en que expresamente se señala que quedan exentos de las obligaciones recién mencionadas.

En este sentido, se hace necesaria una reforma legal que incluya los temas tratados en este trabajo. Si bien en la actualidad se tramita un proyecto de ley que pretende reformar la NLMC, éste no incluye modificaciones sobre estos aspectos, aunque sí pretende incorporar un numeral tres al artículo 65, en aras de lograr "la mantención de los derechos existentes del cónyuge beneficiario en los sistemas de salud del titular de quien es carga, a la fecha de la demanda" ${ }^{\prime \prime 7}$.

\footnotetext{
55 Alessandri; Somarriva, Tratado de los Derechos Reales, cit. n. 47, p. 129.

${ }^{56}$ Alessandri; Somarriva, Tratado de los Derechos Reales, cit. n. 47, p. 130.

${ }^{57}$ Boletín del Senado $N^{\circ}$ 3.536-18, Segundo informe de la comisión de familia recaído en diversos proyectos de ley que modifican normas referidas a la institución del matrimonio, contenidas en la Ley de Matrimonio Civil, el Código Civil, la Ley de Registro Civil, el Código Penal y el Código Tributario, p. 11.
} 
Queda pendiente la discusión sobre el término de la declaración de bien familiar una vez disuelto el matrimonio por sentencia de divorcio, lo que como consecuencia dejaría sin efecto los derechos reales constituidos en virtud del artículo 147 del Código Civil, ya que existe jurisprudencia en ambos sentidos ${ }^{58}$.

Dicha decisión puede generar una cierta incompatibilidad con los derechos que se constituyan a título de compensación económica, tema resuelto en la Ley sobre Pensiones Alimenticias, en el artículo $9^{\circ}$, ya citado, que señala que "cuando el cónyuge alimentario tenga derecho a solicitar, para sí o para sus hijos menores, la constitución de un usufructo, uso o habitación en conformidad a este artículo, no podrá pedir la que establece el artículo 147 del Código Civil respecto de los mismos bienes".

Por último, el pago de la compensación mediante esta modalidad tiene un cierto carácter aleatorio, dado que los derechos reales de goce mencionados, se extinguen con la muerte del beneficiario aun antes del día prefijado para su terminación (arts. 806 y 819 del Código Civil). Así, si se constituye un día y al siguiente fallece el beneficiario, la reparación del menoscabo ni siquiera sería parcial. Recordemos que en el caso de fijar una cantidad de dinero, dicho crédito pasa a los herederos del cónyuge beneficiario.

Con respecto al cónyuge beneficiario, es decir, el más débil, la única disposición que encontramos es la que protege el derecho de los acreedores que tuviere en cualquier tiempo, lo que significa que no integran el derecho de prenda general. Quizás lo mejor sería aplicar lo dispuesto en el artículo 2466 inciso $3^{\circ}$ del Código Civil, agregando que el usufructo constituido a título de compensación no será embargable, como ocurre con el usufructo del marido sobre los bienes de la mujer, o el del padre o madre sobre los bienes del hijo sujeto a patria potestad ${ }^{59}$.

Por supuesto, que la principal protección va estar dada por las medidas que tome el juez y, en definitiva, por los cambios legislativos que, a nuestro juicio, amerita este tema.

Se puede decir que la constitución de derechos reales como modalidad de pago de la compensación es excepcional y que lo usual es la dación en pago del mismo bien, pero en el caso de los bienes raíces, normalmente se adquieren mediante créditos hipotecarios a varios años, lo que en cierta forma impide la posible transferencia de dichos bienes, que por lo general el cónyuge más débil no podrá acreditar ingresos para asumir el crédito.

Por último, se establece una regla de protección de terceros acreedores similar a la del artículo 1723 del Código Civil, característica de los efectos

${ }^{58}$ Cf. Troncoso, "El divorcio como causal de desafectación”, cit. n. 51, pp. 383-390.

${ }^{59}$ Domínguez, "Compensación económica", cit. n. 12, p. 25. 
patrimoniales del matrimonio. Es decir, no se perjudicará a los acreedores que el cónyuge propietario hubiere tenido a la fecha de su constitución. Por lo que dicho derecho será inoponible a los terceros, y, en consecuencia, podrá requerir la realización del inmueble y el adquirente lo recibirá libre de todo gravamen ${ }^{60}$.

Para Pizarro y Vidal "Esta última disposición resulta relevante para el derecho real de usufructo, empero inútil e innecesaria, para el de uso o habitación, al ser inembargable según lo dispone el artículo 1618 del Código Civil" ${ }^{61}$.

\subsection{En caso de insolvencia del deudor ${ }^{62}$. Caso del artículo 66 NLMC}

En caso de insolvencia del cónyuge deudor -supuesto del artículo 66- y para el evento de que no sea posible aplicar alguna de las modalidades anteriores, podrá dividirlo en cuantas cuotas fuere necesario. Para ello, tomará en consideración la capacidad económica del cónyuge deudor y expresará el valor de cada cuota en alguna unidad reajustable (rige lo ya señalado). En este caso aparece como un deber del juez por los términos imperativos de la norma, a diferencia del citado artículo 65 donde se señala podrá.

Así lo ha resuelto la Ilustrísima Corte de Apelaciones de Valparaíso, en la sentencia de fecha 10 de febrero de 2010, en causa Rol № 710-2009, que señala "que en lo relativo al pago de la compensación económica en dinero que se impondrá al marido demandado reconvencional, en mérito de los antecedentes probatorios del juicio relativos a su capacidad económica, hace procedente fijar su pago en cuotas mensuales reajustables, en los términos del artículo 66 de la ley 19.947".

En otras ocasiones se ha considerado la situación de salud del demandado. Así, por ejemplo, en sentencia de la Ilustrísima Corte de Apelaciones de La Serena, de fecha 14 de octubre de 2009, en causa Rol № 180-2009, que señala "que, por otra parte, teniendo muy en cuenta la situación de salud del demandado reconvencional, según se consigna en el considerando décimo del fallo recurrido, donde aparece que padece de Diabetes Mellitus, esta Corte, en uso de las facultades que le confiere el artículo 66 de la Ley 19.947, estima prudente dividir el monto de la compensación económica del cónyuge deudor en 28 cuotas mensuales, iguales y sucesivas".

El artículo 66 NLMC expresa que la cuota respectiva se considerará alimentos para el efecto de su cumplimiento, a menos que se hubieren ofrecido otras

\footnotetext{
${ }^{60}$ En similar sentido, Pizarro; VIdal, La compensación económica, cit. n. 32, p. 102.

${ }^{61}$ Pizarro; Vidal, La compensación económica, cit. n. 32, p. 102.

${ }^{62}$ Así, Turner, "Cauciones en el derecho de alimentos y en el derecho del matrimonio chilenos", cita n. 43, p. 720.
} 
garantías para su efectivo y oportuno pago ${ }^{63}$, lo que se declarará en la sentencia. Esto es lo que constituye la garantía para el beneficiario de la compensación económica, se trata de la protección al cónyuge débil, pero se requiere que el juez lo declare en la sentencia, ya que es un régimen excepcional. Todo lo anterior es, sin perjuicio, de la discusión sobre los apremios personales en caso de incumplimiento ${ }^{64}$.

Sin duda se trata de una situación distinta a la planteada por el artículo 65 NLMC, por lo tanto, la asimilación a los alimentos sólo procede en el caso de insolvencia, sólo para el efecto de exigir su cumplimiento y siempre que no se garantice de otra forma el pago.

Finalmente, es necesario aclarar que para efectos de esta disposición entendemos por deudor insolvente a aquél que no está en condiciones de solucionar el pago de la compensación mediante el pago de contado o en un número reducido de cuotas y que no tiene otros bienes para proceder al pago o para constituir derechos reales. En definitiva, es aquel que no puede pagar mediante alguna de las formulas del artículo 65 NLMC.

\subsection{Traspaso de fondos previsionales}

En esta materia el legislador ha mostrado gran preocupación, tanto es así que la ley No 20.255, publicada el 17 de marzo de 2008, que establece la Reforma Previsional, dedica dos artículos a la compensación económica en los casos de divorcio o nulidad de matrimonio ${ }^{65}$. Dichas disposiciones entraron en

${ }^{63}$ Con respecto a la expresión otras garantías, vale lo señalado en el apartado sobre el pago en cuotas del art. 65 NLMC, específicamente, respecto a las seguridades para el pago.

${ }^{64}$ Cf. Lepín, La compensación económica, cit. n. 1, pp. 148 y 149.

${ }^{65}$ Ley No 20.255, artículo 80: "Al considerar la situación en materia de beneficios previsionales a que se refiere el artículo 62 de la ley $N^{\circ} 19.947$, sobre Matrimonio Civil, y ello origine total o parcialmente un menoscabo económico del que resulte una compensación, el juez, cualquiera haya sido el régimen patrimonial del matrimonio, podrá ordenar el traspaso de fondos desde la cuenta de capitalización individual afecta al decreto ley $N^{\circ} 3.500$, de 1980, del cónyuge que deba compensar a la cuenta de capitalización del cónyuge compensado o de no existir ésta, a una cuenta de capitalización individual, que se abra al efecto.

Dicho traspaso, no podrá exceder del 50\% de los recursos acumulados en la cuenta de capitalización individual del cónyuge que debe compensar, respecto de los fondos acumulados durante el matrimonio".

Ley $N^{\circ}$ 20.255, artículo 81: "La Superintendencia de Pensiones deberá tener a disposición de los tribunales estudios técnicos generales que contribuyan a resolver con bases objetivas la situación previsional que involucre a cónyuges. De estimarlo necesario, el juez podrá requerir al citado organismo antecedentes específicos adicionales.

La Superintendencia establecerá, mediante norma de carácter general, los procedimientos aplicables en los traspasos de fondos, apertura de las cuentas de capitalización individual que se requirieran y demás aspectos administrativos que procedan". 
vigencia el primero de octubre de 2008, y se aplicarán a los juicios de divorcio o nulidad que se inicien con posterioridad a dicha fecha ${ }^{66}$.

No se trata de una compensación distinta, sino, tal como lo señala el artículo 80 de esta ley, anteriormente citado, considera la situación en materia de beneficios previsionales a que se refiere el artículo 62, es decir, permite al juez cuantificar o mensurar el daño previsional, lo que de ningún modo restringe la compensación sólo a los fondos que se puedan traspasar. Es decir, la demandante podrá solicitar el traspaso de hasta el 50\% de los fondos y una suma determinada de dinero, en forma conjunta o una en subsidio de la otra.

La reforma faculta al juez para ordenar el traspaso de fondos (se entiende en propiedad) desde la cuenta de capitalización individual del cónyuge deudor a la del cónyuge acreedor, y si éste no posee una, se ordenará que se proceda a abrir una al efecto.

Señalamos que se trata de una facultad del juez, pues la redacción del precepto utiliza el término "podrá" ordenar el traspaso de fondos. Además, exige que se acredite un menoscabo, a lo menos parcial, y que se aprecie en el marco de la situación en materia de beneficios previsionales.

En este sentido resulta dudoso el acuerdo de las partes en esta materia, toda vez que por regla general estos fondos de pensiones son indisponibles para las partes y el precepto no lo autoriza.

El límite está establecido en el 50\% de los recursos acumulados en la cuenta de capitalización individual del deudor durante el matrimonio.

Es menester considerar que dichas normas se aplican sólo a quienes se encuentran en el sistema de fondos de pensiones (AFP), y no a quienes cotizan en el Instituto de Normalización Provisional (INP), o en las Cajas de Previsión de las Fuerzas Armadas. Esta situación no corresponde a una discriminación, ya que, en estos últimos casos no se puede aplicar, dado que la reforma sólo se refiere a las personas que se encuentran en el sistema de AFP, que es de capitalización individual y, por lo tanto, es factible determinar el monto y proceder al traspaso. En cambio, en los otros sistemas solidarios de pensiones, los afiliados no disponen de sus fondos sino hasta el momento de su jubilación.

Ahora, nada impide que se decrete como forma de pago la retención de un porcentaje de la pensión que el cónyuge deudor reciba.

El beneficio deberá solicitarse en la demanda, a efecto que las partes aporten durante el juicio la información necesaria, para que el juez pueda ordenar el

${ }^{66}$ Ley № 20.255, artículo vigésimo quinto transitorio: “las normas contenidas en el Párrafo $2^{\circ}$ del Título III entrarán en vigencia el primer día del séptimo mes siguiente al de su publicación en el Diario Oficial y sólo serán aplicables en los juicios de nulidad o divorcio que se inicien con posterioridad a dicha fecha". 
traspaso de dichos recursos, los que van en definitiva a quedar a disposición del cónyuge beneficiario en la época de su jubilación.

Por último, el organismo que debe informar al tribunal, proporcionar informes técnicos generales y específicos, y reglamentar el procedimiento administrativo aplicable al traspaso, es la Superintendencia de Pensiones, por lo que se deberá oficiar al efecto.

\section{CONCLUSIONES}

1. El principio de protección del cónyuge más débil es una norma orientadora para el juez en los juicios sobre ruptura matrimonial, que busca darle protección desde el punto de vista económico, y que habilita al juzgador para darle contenido en cada caso concreto que se someta a su conocimiento.

2. La compensación económica se puede regular por los cónyuges, sin más límites que los derivados de su voluntad, lo que implica que puedan renunciar al derecho, pactar el monto y las cuotas que estimen e, incluso, puedan establecer el pago de una renta vitalicia. Así fluye de los artículos 63 y 64 NLMC que resulta ser un nuevo avance en el principio de la autonomía privada en el Derecho de Familia.

3. La carga de proteger al cónyuge débil la impone el legislador al juez para que fije el monto de la prestación en unidades reajustables y establezca seguridades para el pago de la compensación, lo que se puede materializar en el establecimiento de cauciones reales o personales, o en cualquier otro mecanismo que garantice o facilite el pago de la prestación.

4. La ley establece un orden de prelación para determinar la forma de pago, siempre que sea decretada por el juez, siendo la regla general la prestación única pagadera de una sola vez y, en subsidio, si no es posible regularlo de esa forma, se podrá establecer la entrega de una suma de dinero, acciones u otros bienes o la constitución de derechos reales de goce sobre bienes de propiedad del deudor, y sólo en caso de insolvencia, fijar el número de cuotas necesarias. De no ser posible aplicar las modalidades anteriores puede el juez establecer otra modalidad de pago. Consideramos, además, que en todos los casos señalados se podrá también ordenar el traspaso de fondos de pensiones, de acuerdo al artículo 80 de la ley $\mathrm{N}^{\circ} 20.255$, en forma conjunta o subsidiaria.

5. A diferencia de la regulación sobre la constitución de los derechos reales regulados en sede de alimentos o de bien familiar, el legislador fue bastante más parco, señalando solamente que el juez podrá constituir derechos de usufructo, uso o habitación, respecto de bienes que sean de propiedad del cónyuge deudor, sin mencionar nada sobre la prohibición de enajenar o gravar, sobre la posibilidad de eximir al beneficiario de la confección de inventario o que la resolución sirva de título para inscribir el derecho real o la prohibición, en su caso. 


\section{BibLIOGRAFíA}

Alessandri Rodríguez, Arturo; Somarriva Undurraga, Manuel, Tratado de los Derechos Reales, T. II, Editorial Jurídica de Chile, Santiago, quinta edición, 1993.

Boletín del Senado No 1.759-18, Informe de la Comisión de Constitución, Legislación, Justicia y Reglamento del Senado.

Boletín del Senado No 3.536-18, Segundo informe de la comisión de familia recaído en diversos proyectos de ley que modifican normas referidas a la institución del matrimonio, contenidas en la Ley de Matrimonio Civil, el Código Civil, la Ley de Registro Civil, el Código Penal y el Código Tributario.

Bossert, Gustavo y ZANNONI, Eduardo, Manual de derecho de familia, Editorial Astrea, Buenos Aires, sexta edición, 2007.

CoRdero CUtILlas, Iciar, El convenio regulador en las crisis matrimoniales (estudio jurisprudencial), Editorial Aranzandi, Navarra, 2004.

Corral Talciani, Hernán, "La compensación económica en el divorcio y la nulidad matrimonial", Revista Chilena de Derecho, Vol. 34, № 1, Santiago, 2007.

Domínguez Hidalgo, Carmen, "Compensación económica en la nueva ley de matrimonio civil", Seminario del Colegio de Abogados, charla efectuada 13 de octubre, Santiago, 2005.

Domínguez Hidalgo, Carmen, "El convenio regulador y la compensación económica: una visión de conjunto", en Assimakópulos FiguerOA, Anastasia y CORRAL TALCIANI, Hernán (Eds.) Matrimonio civil y divorcio, análisis crítico y criterios para la aplicación de la Ley N 19.947, Universidad de Los Andes, Santiago, 2005.

Ducci Claro, Carlos, Derecho Civil. Parte general, Editorial Jurídica de Chile, Santiago, cuarta edición, 2009.

Gómez de la Torre Vargas, Maricruz, "Compensación económica en la nueva ley de matrimonio civil", Seminario Colegio de Abogados charla efectuada el 20 de octubre, Santiago, 2005.

Guerrero Becar, José, "Menoscabo y compensación económica. Justificación de una visión asistencial", Revista Derecho (Valdivia), Vol. 21, №2, 2008.

HÜBNER GUZMÁn, Ana, "La nueva Ley de matrimonio civil: panorama y estructura general", en Assimakópulos Figueroa, Anastasia y Corral Talciani, Hernán (Eds.) Matrimonio civil y divorcio, análisis crítico y criterios para la aplicación de la Ley N 19.947, Universidad de Los Andes, Santiago, Chile, 2005.

InStituto LiBERTAD y Desarrollo, "Divorcio unilateral empeora la situación de la mujer". En: <http://www.lyd.com/programas/legislativo/divorcio> [visitado el 10/06/2011]. 
LePIN Molina, Cristián, La compensación económica. Efecto patrimonial de la terminación del matrimonio. Editorial Jurídica de Chile, Santiago, 2010.

Orrego Acuña, Juan, Análisis de la Nueva Ley de Matrimonio Civil, Metropolitana, Santiago, 2004.

Pizarro Wilson, Carlos; Vidal Olivares, Álvaro, La compensación económica por divorcio o nulidad de matrimonio, Editorial LegalPublishing, Santiago, 2009.

Rodríguez Grez, Pablo, Ley de matrimonio civil, en: <www.abogados.cl> [visitado el 10/06/2010].

Troncoso Larronde, Hernán, "El divorcio como causal de desafectación de un bien declarado familiar. Comentario a un fallo reciente", en Estudios de Derecho Civil V, Jornadas Nacionales de Derecho Civil, Concepción 2009, Editorial LegalPublishing, Santiago, 2010.

Turner Saelzer, Susan, "Cauciones en el derecho de alimentos y en el derecho del matrimonio chilenos", En Estudios sobre las garantías reales y personales, en homenaje a Manuel Somarriva Undurraga, T. II, editorial Jurídica de Chile, Santiago, 2008.

Veloso Valenzuela, Paulina, "Algunas reflexiones sobre la compensación económica", Revista Actualidad Jurídica, Facultad de Derecho, Universidad del Desarrollo, № 13, Santiago, 2006.

Vidal Olivares, Álvaro, "Formas de pago y la protección del derecho a la compensación económica por divorcio o nulidad", Revista Chilena de Derecho Privado, № 12, julio 2009.

Vodanovic Haklicka, Antonio, Derecho de alimentos, Editorial LexisNexis, Santiago, cuarta edición, 2004.

VVAA, Convenios reguladores de las relaciones paterno-filiales y patrimoniales en las crisis del matrimonio, Ediciones Universidad de Navarra, Navarra, segunda edición, 1989.

\section{JURISPRUDENCIA}

Corte Suprema

Sentencia de la Excma. Corte Suprema, de 19 de abril de 2006, Rol № 1.6502006.

Sentencia de la Excma. Corte Suprema, de 21 de junio de 2006, Rol No 5742006.

Sentencia de la Excma. Corte Suprema, de 21 de junio de 2006, Rol № 2.1742006.

Sentencia de la Excma. Corte Suprema, de 30 de enero de 2007, Rol № 962007. 
Sentencia de la Excma. Corte Suprema de 7 de marzo de 2007, Rol No $794-$ 2007.

Sentencia de la Excma. Corte Suprema de 7 de marzo de 2007, Rol No 1.0872007.

Sentencia de la Excma. Corte Suprema de 12 de marzo de 2007, Rol № 5.0482006.

Sentencia de la Excma. Corte Suprema, de 7 de mayo de 2007, Rol No 5.6162006.

Sentencia de la Exma. Corte Suprema, de 30 de julio de 2007, Rol № 2.7762007.

Sentencia de la Excma. Corte Suprema, de 24 de marzo de 2008, Rol № 532008.

Sentencia de la Excma. Corte Suprema, de 6 de abril de 2009, Rol No 7272009.

Sentencia de la Excma. Corte Suprema, de 27 de abril de 2009, Rol No 9042009.

Sentencia de la Excma. Corte Suprema, de 1 de junio de 2009, Rol No 3.0792009.

Sentencia de la Excma. Corte Suprema, de 7 de julio de 2009, Rol № 1.3702009

Sentencia de la Excma. Corte Suprema, de 29 de julio de 2009, Rol № 3.9112009.

\section{Cortes de Apelaciones}

Sentencia de la Iltma. Corte de Apelaciones de Santiago, de 15 de septiembre de 2005, Rol No 10.228-2005.

Sentencia de la Iltma. Corte de Apelaciones de Santiago, de 26 de septiembre de 2005, Rol No 5.895- 2005.

Sentencia de la Iltma. Corte de Apelaciones de La Serena, de 2 de diciembre de 2005, Rol No 977-2005.

Sentencia de la Iltma. Corte de Apelaciones de Valdivia, de 22 de diciembre de 2005, Rol № 959-2005.

Sentencia de la Iltma. Corte de Apelaciones de Antofagasta, de 11 de abril de 2006, Rol No 69-2006.

Sentencia de la Iltma. Corte de Apelaciones de Antofagasta, de 12 de abril de 2006, Rol No 52-2006.

Sentencia de la Iltma. Corte de Apelaciones de Antofagasta, de 3 de mayo de 2006, Rol No 1.161- 2005. 
Sentencia de la Iltma. Corte de Apelaciones de Rancagua, de 16 de mayo de 2006, Rol No 1.603-2005.

Sentencia de la Iltma. Corte de Apelaciones de Rancagua, de 25 de mayo de 2006, Rol No 266-2006.

Sentencia de la Iltma. Corte de Apelaciones de Antofagasta, de 29 de mayo de 2006, Rol № 225-2006.

Sentencia de la Iltma. Corte de Apelaciones de Antofagasta, de 13 de julio de 2006, Rol No 372-2006.

Sentencia de la Iltma. Corte de Apelaciones de Arica, de 5 de agosto de 2008, Rol No 390- 2008.

Sentencia de la Iltma. Corte de Apelaciones de Concepción, de 6 de agosto de 2008, Rol No 498-2008.

Sentencia de la Corte de Apelaciones de Concepción, de 24 de febrero de 2009, Rol No 1.707-2008.

Sentencia del la Iltma. Corte de Apelaciones de La Serena, de 16 de abril de 2008, Rol No 218-2008.

Sentencia de la Corte de Apelaciones de Punta Arenas, de 9 de febrero de 2009, Rol No 307-2008.

Sentencia de la Iltma. Corte de Apelaciones de Puerto Montt, de 2 de julio de 2009, Rol No 82-2009.

Sentencia de la Iltma. Corte de Apelaciones de Temuco, de 26 de julio de 2011, Rol No683-2011. 
